\title{
NIEPEWNOŚĆ I RYZYKO JAKO KATEGORIE ANALIZY FUNKCJONOWANIA ŚRODOWISKA MIĘDZYNARODOWEGO NA PRZYKŁADZIE BADAŃ ROZWOJU SYTUACJI MIĘDZYNARODOWEJ W REGIONIE ARKTYKI NA POCZĄTKU XXI WIEKU ${ }^{1}$
}

\author{
Michał Łuszczuk \\ Uniwersytet Marii Curie-Skłodowskiej w Lublinie \\ Wydział Politologii, Zakład Stosunków Międzynarodowych \\ adres, e-mail:mluszczuk@gmail.com
}

Streszczenie. W artykule podjęto rozważania dotyczące znaczenia oraz badania wpływu niepewności oraz ryzyka na funkcjonowanie współczesnego środowiska międzynarodowego. Korzystając $\mathrm{z}$ analizy rozwoju sytuacji międzynarodowej w regionie Arktyki na początku XXI wieku wskazano na czym polega oddziaływanie zmian klimatu jako źródeł niepewności oraz w jaki sposób współpraca międzynarodowa coraz częściej zarządzania ryzykiem.

Słowa kluczowe: ryzyko, niepewność, analiza stosunków międzynarodowych, Arktyka

\section{WSTĘP}

Specyfika współczesnego środowiska międzynarodowego, określanego coraz częściej mianem późno lub post-westfalskiego, obejmuje między innymi „,nową jakość współzależności międzynarodowych, wzajemne warunkowanie wnętrza państwa i środowiska międzynarodowego, wzrost nieliniowości i niestabilności środowiska społecznego oraz stymulowanie zjawisk przeciwstawnych". ${ }^{2}$ Kumulacja tych atrybutów w połączeniu z obserwowanymi następstwami zmian klimatu

1 Badania zostały sfinansowane ze środków Narodowego Centrum Nauki (NCN) przyznanych w ramach finansowaniu stażu po uzyskaniu stopnia naukowego doktora na podstawie decyzji numer DEC-2012/04/S/HS5/00172.

2 M. Pietraś, Istota i ewolucja międzynarodowych stosunków politycznych, [w:] Międzynarodowe stosunki polityczne, M. Pietraś (red.), Wydawnictwo UMCS, Lublin 2007, s. 38 
sprawia $^{3}$, iż dokonanie miarodajnej i trafnej analizy funkcjonowania środowiska międzynarodowego, służącej m.in. podejmowaniu decyzji dotyczących różnych obszarów życia społecznego, jak i prognozowaniu dalszego rozwoju sytuacji międzynarodowej, staje się coraz trudniejsze. Przykładem potwierdzającym zasadność przedstawionej tezy, a jednocześnie dobrze ilustrującym powyższą charakterystykę, jest rozwój sytuacji międzynarodowej w regionie Arktyki na początku XXI wieku. ${ }^{4}$

Daleka Północ za sprawą nasilających się następstw zmian klimatu, procesów modernizacji i globalizacji, przestaje już być traktowana przez społeczność międzynarodową jako jedynie odległa i niezamieszkana kraina mrozu i śniegu. Coraz częściej i powszechniej jest natomiast postrzegana jako jedno z kluczowych miejsc współkształtujących globalne procesy klimatyczno-ekologiczne oraz potencjalnie jako bardzo ważny element światowego ładu politycznego, społecznego, ekonomicznego. ${ }^{5}$

Równocześnie, wraz ze stopniowym wzrostem wiedzy na temat wielowymiarowej roli Arktyki w skali światowej, wzrasta także świadomość wielkiej niepewności dotyczącej dalszego funkcjonowania tego regionu i jego oddziaływania na świat. Dostrzec to można, zarówno w działaniach podejmowanych przez różne kategorie uczestników stosunków międzynarodowych zaangażowanych w Arktyce, w analizach naukowych lub eksperckich, jak też w codziennych relacjach różnych mediów poświęconych Dalekiej Północy. Nikt nie jest pewien, jakie będą kierunek, tempo, zakres oraz konsekwencje dokonującej się obecnie w Arktyce transformacji. ${ }^{6}$ Podczas gdy dla jednych ,otwieranie się” Arktyki to początkowa faza ekologicznej i społecznej katastrofy, która wyniszczy ten region w nadchodzących dekadach (następnie obejmie zaś cały świat), to dla drugich jest to wstęp do bardzo obiecującego rozwoju gospodarczo-społecznego opartego przede wszystkim na eksploatacji arktycznego „Eldorado”. Ujmując to krótko: przyszłość Arktyki jawi się dziś jako zagrożenie albo szansa.

Jakkolwiek to przyszłość zweryfikuje, które przypuszczenia były słuszne, a które błędne, to już dziś podejmowane są wielokierunkowe działania transgraniczne na rzecz zapewnienia Dalekiej Północy - w obliczu dokonującej

3 A. Giddens, Klimatyczna katastrofa, Wydawnictwo Pruszyński i S-ka. Pruszyński Media, Warszawa 2010; P.G. Harris, The Politics of Climate Change: Environmental Dynamics in International Affairs, Routledge, Abingdon 2009; D. Brodawka, Zmiany klimatu jako nowe zagrożenie bezpieczeństwa, Fundacja Studiów Międzynarodowych, Warszawa 2009; M. Pietraś, Globalny Problem zmian klimatu. Analiza politologiczna, „Teka Komisji Politologii i Stosunków Międzynarodowych - Oddział Lubelski PAN" 2010, nr 5, s. 5-35.

4 Zob. szerzej: Arktyka na początku XXI wieku, M. Łuszczuk, Wydawnictwo UMCS, Lublin 2013.

5 Arctic Human Development Report, Stefansson Arctic Institute, Akureyri 2004; Arctic Human Development Report: Regional Processes and Global Linkages. Volume II (2010-2014), J. N. Larsen, G. Fondahl (eds), Nordic Council of Ministers, Copenhagen 2015.

6 P. Arbo, A. Iversen, M. Knol, T. Ringholm, G. Sander, Arctic futures: conceptualizations and images of a changing Arctic, "Polar Geography" 2012, t. 36, nr 3. 163-182. 
się transformacji - wielowymiarowego bezpieczeństwa. W ich przygotowanie szczególnie jest zaangażowana Rada Arktyczna, której podstawowym obszarem aktywności stała się w ostatnich latach szeroko rozumiana identyfikacja zagrożeń oraz wskazywanie środków zaradczych. Wiele argumentów wskazuje na to, iż Rada Arktyczna stanowi forum ukierunkowane na zarządzanie ryzykiem na Dalekiej Północy.

Celem niniejszego opracowania - w wymiarze empirycznym poświęconego regionowi Arktyki - jest, po pierwsze, rozważenie znaczenia niepewności jako czynnika rozwoju sytuacji międzynarodowej, a pośrednio też jako ważnej determinanty funkcjonowania współczesnego środowiska międzynarodowego. Po drugie, udzielenie odpowiedzi na pytanie, w jakim zakresie kategoria ryzyka oraz koncepcja zarządzania ryzykiem jest wykorzystywana w ocenie perspektyw rozwoju sytuacji międzynarodowej w regionie Arktyki.

Artykuł składa się z pięciu części. Po niniejszym wstępie przedstawione zostaną rozważania dotyczące kategorii niepewności oraz ryzyka w kontekście ich znaczenia dla funkcjonowania współczesnego środowiska międzynarodowego.

W części trzeciej zarysowana zostanie kwestia zmian klimatu w Arktyce jako czynnika określającego relacje między aktorami zaangażowanymi w tym regionie. Analiza ta nawiąże do pojęcia „bezgranicznego ryzyka” zaproponowanego przez U. Becka i A. Giddensa. W części czwartej poddana zostanie analizie rola Rady Arktycznej jako instytucji ukierunkowanej na zarządzanie ryzykiem w Arktyce i służącej interesom państw arktycznych w odniesieniu do stanu środowiska naturalnego regionu oraz jego perspektyw jego rozwoju na płaszczyźnie gospodarczej. Opracowanie zakończy krótkie podsumowanie.

\section{NIEPEWNOŚĆ I RYZYKO JAKO CZYNNIKI WPŁYWAJĄCE NA FUNKCJONOWANIE WSPÓŁCZESNEGO ŚRODOWISKA MIĘDZYNARODOWEGO}

Nie zapominając, że brak pewność dotyczący efektów podejmowanych decyzji oraz czynności jest stałym atrybutem wszelkiej działalności człowieka, również w sferze stosunków międzynarodowych, warto zauważyć, iż funkcjonowanie środowiska międzynarodowego na początku XXI wieku wskazuje, iż zakres niepewności ulega w ostatnim czasie istotnemu zwiększeniu. Pojawiają się w związku z tym pytania: czym jest niepewność, jaką rolę odgrywa w polityce międzynarodowej i jak oceniać jej znaczenie?

Niepewność stanowi kategorię poznaczą o charakterze wielowymiarowym ${ }^{7}$, której istotą jest brak możliwości określenia prawdopodobieństwa zaistnienia ewentualnych wariantów rozwoju danej sytuacji, np. w następstwie podjętej de-

7 E. Dziel, Niepewność i ryzyko w działalności gospodarczej, „Periodyk Naukowy Akademii Polonijnej” 2011, t. 5, nr 1, s. 135-144. 
cyzji. Jak wskazuje E. Dziel, „Niepewność jest niepoliczalna (niemierzalna), tzn. brak jest statystycznych parametrów dla oszacowania możliwości powstania zdarzenia losowego. Dotyczy to głównie zdarzeń pojedynczych, nietypowych". ${ }^{8}$

Jak zauważa B. Rathbun, oddziaływanie niepewności od zawsze stanowiło przedmiot refleksji w ramach głównych nurtów badawczy w zakresie nauki o stosunkach międzynarodowych, co sprawia, iż obecnie w ramach każdego paradygmatu funkcjonuje odmienne rozumienie tego zjawiska. Dla realistów niepewność to synonim zagrożeń wynikających _wynik anarchii środowiska międzynarodowego, dla zwolenników podejścia racjonalistycznego niepewność stanowi naturalny element gier negocjacyjnych. Zgodnie z podejściem z zakresu decydowania politycznego niepewność to właściwość sytuacji decyzyjnej, podczas gdy dla konstruktywistów to jedynie pewna niedookreśloność w systemie społecznych norm i tożsamości. ${ }^{9}$ Co ciekawe, istnieją daleko idące rozbieżności w ocenie znaczenia niepewności dla funkcjonowania środowiska międzynarodowego, gdyż jak wskazuje E. Baggot, podczas gdy dla jednych badaczy (Waltz, Mearsheimer) niepewność jest źródłem konfliktów i wojen, to jednocześnie dla innych (Deutsch, Singer) jest wręcz przeciwnie - niepewność skłania państwa do bardziej ostrożnych działań i tym samym ogranicza prawdopodobieństwo wystąpienia konfliktów. ${ }^{10}$

Wydaje się, iż zjawisko niepewności, mając różne oblicza i stosowane w różnych kontekstach, mimo wszystko stale oddziałuje na sytuację międzynarodową, przy czym istotę tego oddziaływania stanowi fakt, iż funkcją niepewności jest ryzyko. Oznacza to, że im większy jest zakres niepewności, tym większe jest ryzyko. Ryzyko w przeciwieństwie do niepewności jest jednak mierzalne, co oznacza, iż „ryzyko występuje wówczas, gdy wynik danego działania lub decyzji może być określony za pomocą jednego z trzech rodzajów prawdopodobieństwa: matematycznego, statystycznego i szacunkowego". ${ }^{11}$ Jak wyjaśnia A. Moraczewska, ,nadanie niepewnej rzeczywistości cech ryzyka pozwala na jej lepsze poznanie, skwantyfikowanie, ocenę prawdopodobieństwa strat i zysków, a tym samym uzyskanie poczucia kontroli nad nią i nad przyszłością". ${ }^{12}$

Zazwyczaj ryzyko jest postrzegane jako niebezpieczeństwo podjęcia błędnych decyzji i niepowodzenia określonego działania, lecz w istocie jego treścią

${ }^{8}$ Ibidem, s. 137.

${ }^{9}$ B. C. Rathbun, Uncertain about Uncertainty: Understanding the Multiple Meanings of a Crucial Concept in International Relations Theory, "International Studies Quarterly» 2007, t 51, nr 3. s. 533-557.

${ }^{10}$ E. Baggott, The Security Dilemma in US-China Relations: Uncertainty and Perception Formation, referat wygłoszony na konferencji: New Directions in Analyzing Text as Data Conference, September 27-28, 2013, London, dostępny na: http://www.kenbenoit.net/pdfs/NDATAD2013/US-China\%20Relations\%20Baggott.pdf, (dostęp: 20.02.2015).

${ }^{11}$ E. Dziel, op. cit., s. 138.

${ }^{12}$ A. Morczewska, Wymiar wschodni Europejskiej Polityki Sąsiedztwa jako strategia zarzadzania ryzykiem, ,Przegląd Zachodni” 2014, nt. 4, s. 40. 
jest alternatywa: sukces lub niepowodzenie, zysk lub strata, nagroda lub kara. ${ }^{13}$ Dokonując dokładniejszej analizy okoliczności występowania ryzyka, należy podkreślić, iż w ujęciu systemowym ryzyko to funkcja zagrożenia, wrażliwości i wpływu, gdzie zagrożenie jest zjawiskiem powstałym w wyniku występowania określonej siły o istotnym znaczeniu dla dalszego istnienia oraz bezpieczeństwa systemu, wrażliwość to zdolność tego systemu do reagowania na zagrożenia, zaś wpływ to zakres zmian potencjalnie wywołanych przez oddziaływania siły na system. Opierając się na klasyfikacji ryzyka według kryterium niepewności ${ }^{14}$, można wskazać, że niepewność może wiązać się z co najmniej dwoma ze wskazanych uwarunkowań ryzyka. Po pierwsze, może dotyczyć zagrożenia (niepewność czasu oraz miejsca jego wystąpienia), po drugie odnosić się do wpływu (niepewność skutku). W tym kontekście, uzasadniona jest ocena, iż ryzyko to efekt niedoskonałości człowieka, który nie potrafi poznać i zrozumieć świata, w którym żyje i który częściowo jest wytworem jego świadomej lub nieświadomej działalności. ${ }^{15}$

Analiza ryzyka, od dawna rozwijana na gruncie nauk ekonomicznych i matematycznych, w obrębie nauki o stosunkach międzynarodowych znalazła się dopiero kilkanaście lat temu w związku ze wzrostem zainteresowania państw oraz organizacji międzynarodowych zagadnieniami dotyczącymi zarządzania ryzykiem $w$ takich dziedzinach jak walka $z$ terroryzmem, regulacja rynków finansowych czy opieka zdrowotnej. ${ }^{16}$ Prowadzone obecnie badania, opierające się w dużej mierze na koncepcjach wywodzących się z socjologii, koncentrują się na społecznych i politycznych aspektach szacowania i zarządzania ryzykiem.

Zakres tych badań jest bardzo zróżnicowany, co można wyjaśnić między innymi postępującą internacjonalizacji życia społecznego, procesami rozwoju wielowymiarowych współzależności oraz globalizacją. Ważną rolę pełni w tym przypadku także wzrost świadomości zarówno decydentów, jak i ekspertów na temat poszerzającego się spektrum zjawisk i procesów wpływających na rozwój sytuacji międzynarodowej, a generujących niepewności oraz ryzyko. Wśród obszarów niepewności znajdują się takie problemy, jak epidemie i pandemie, zmiany klimatu, kwestie dotyczące bezpieczeństwa, szczególnie energetycznego i ekologiczne. Wydaje się, iż z kolei zachowania samych aktorów na arenie międzynarodowej mogą być rozpatrywane w kontekście ryzyka. Szczególnie w kontekście ich zdolności do wpływania na pozostałych uczestników, jak też własnej podatności (wrażliwości) na rzeczywiste i potencjalne zagrożenia. W obliczu współczesnej złożoności wzajemnych powiązań bardzo trudno określić jasne uwarunkowania czy prawidłowości - ryzyko (choć związane z różnymi zagrożeniami) dotyczy bowiem zarówno mocarstw, jak i państw upadających.

${ }^{13}$ E. Dziel, op. cit., s. 138.

${ }^{14}$ D. Dziawgo, Credit-rating, PWN, Warszawa 1998, s. 16: za E. Dziel, op. cit., s. 139.

${ }^{15}$ E. Dziel, op. cit., s. 140.

${ }^{16}$ S. Hameiri, F.P. Kühn, Introduction: Risk, Risk Management and International Relations, "International Relations" 2011, t. 25, nr 3, s. 275-279. 
Warto w tym miejscu wskazać na dwa główne nurty refleksji dotyczące tego tematu: koncepcje , refleksyjnej modernizacji” proponowanej przez U. Beck'a oraz A. Giddensa ${ }^{17}$ oraz poglądy wywodzące się z prac M. Douglas (kulturowy konstruktywizm) i M. Foucault [perspektywa „rządomyślności” (governmentality)]. ${ }^{18}$ Pomimo, iż koncepcje te, pozostając w pewnej opozycji względem siebie ${ }^{19}$ (choć może raczej koncentrują się na różnych stronach tego samego problemu), nie oferują w pełni przekonujących wyjaśnień źródeł ryzyka i dążenia instytucji politycznych do zarządzania nim ${ }^{20}$, to mogą stanowić ciekawy punkt odniesienia do analizy zagadnienia niepewności i ryzyka w rozwoju sytuacji międzynarodowej w regionie Arktyki.

\section{ZMIANA KLIMATU W ARKTYCE JAKO ŹRÓDŁO NIEPEWNOŚCI LUB BEZGRANICZNE RYZYKO ${ }^{21}$}

Jak już wspomniano Arktyka jest coraz powszechniej postrzegana jako jeden z głównych regulatorów globalnego klimatu, a jednocześnie też jako wskaźnik tempa i zakresu globalnych zmian klimatycznych. ${ }^{22} \mathrm{Z}$ tego powodu następstwa zmian klimatu w Arktyce stały się przedmiotem wzrastającego zainteresowania nie tylko państw i społeczeństw arktycznych, ale też państw spoza regionu, organizacji międzynarodowych oraz organizacji pozarządowych, jak chociażby WWF czy Greenpeace. Co ciekawe, wielu aktorów spoza regionu - szczególnie z kręgu państw azjatyckich - traktuje zmiany klimatyczne jako argument legitymizujący ich obecność (na razie tylko naukową) w regionie. Warto też zwrócić uwagę, iż pomimo znaczenia zmian klimatycznych dla samej Arktyki, region nie jest - jak

${ }^{17}$ Zob.: U. Beck, A. Giddens, S. Lash, Modernizacja refleksyjna: polityka, tradycja i estetyka w porzadku społecznym nowoczesności, Wydawnictwo Naukowe PWN, Warszawa 2009.

${ }^{18}$ M. J. Williams, (In)Security Studies, Reflexive Modernization and the Risk Society, "Cooperation and Conflict" 2008, t. 43, nr 1, s. 57-79; M. Merlingen, Governmentality. Towads a Foucauldian Framework for the Study of IGOs, "Cooperation and Conflict" 2008, t. 38, nr 4, s. 361-384.

${ }^{19}$ Zob. W. Clapton, Risk in International Relations, "International Relations" 2011, t. 25, nr 3, s. 280-295.

${ }^{20}$ S. Hameiri, State Transformation, Territorial Politics and the Management of Transnational Risk, "International Relations" 2011, t. 25, nr 3, s. 275-279.

${ }^{21}$ Zawarty w tej części artykułu opis zakresu zmian klimatycznych oraz ekologicznych w Arktyce pochodzi z opracowania: A. Stępień, Zmiany klimatyczne i ochrona środowiska, [w:] Cele i środki polityki arktycznej Polski, M. Łuszczuk, P. Graczyk, A. Stępień, M. Śmieszek, Departament Polityki Europejskiej MSZ RP, Warszawa 2015.

${ }^{22}$ Zgodnie z raportem IPCC, ocieplanie się globalnego klimatu jest „niewątpliwe”. Jak wskazują autorzy tego raportu, główną przyczyną trendu ocieplenia jest spowodowany przede wszystkim działalnością człowieka wzrost zawartości dwutlenku węgla w atmosferze. Zob.: Climate Change 2013: The Physical Science Basis: Working Group I Contribution to the IPCC Fifth Assessment Report, Cambridge University Press, Cambridge 2013, dostępne na: http://www.ipcc.ch/report/ar5/ wg1/ (dostęp: 15.02.2015). Por.: S. Duyck, Which Canary in the Coalmine? The Arctic in the International Climate Change Regime, "The Yearbook of Polar Law" 2012, t. 4, s. 583-617. 
na razie - w sposób szczególny widoczny w negocjacjach prowadzonych pod egidą ramowej konwencji klimatycznej. ${ }^{23}$

Zmiany klimatu są obecnie określane jako największe wyzwanie dla Arktyki. Region jest szczególnie na nie narażony ze względu na proces „wzmocnienia arktycznego", którego efektem jest dwukrotnie szybsze ocieplanie się Arktyki w porównaniu ze średnią światową. Zjawisko to jest rezultatem, między innymi, większej absorpcji energii słonecznej przez coraz mniej pokryte pokrywą śnieżną i lodową powierzchnie wód i lądów (mających tym samym wyższy współczynnik albedo). Obecnie coraz więcej uwagi poświęca się w analizie zmian klimatu krótkotrwałym zanieczyszczeniom klimatycznym (zaliczają się do nich: sadza, a przede wszystkim jej główny składnik tzw. black carbon czyli amorficzna postać węgla, metan, ozon występujący w troposferze oraz związki freonu).

Już obecnie można dostrzec bezprecedensowe przeobrażenia zachodzące w arktycznym środowisku lądowym i wodnym charakteryzujące się daleko posuniętymi zmianami w kriosferze, hydrologii, siedliskach przyrodniczych, różnorodności biologicznej, jak też wpływem na sposób życia w regionie, zarówno ten tradycyjny jak i współczesny. ${ }^{24} \mathrm{Z}$ tego też powodu, zmiany klimatu zostały uznane za największe zagrożenie dla arktycznej różnorodności biologicznej w raporcie grupy roboczej Rady Arktycznej tzw. CAFF z 2013 roku. ${ }^{25}$

Najbardziej widocznym i najczęściej dyskutowanym skutkiem zmian klimatu jest zanik pokrywy lodowej na Oceanie Arktycznym; zwłaszcza kolejne rekordy minimalnego zasięgu letniej (wrzesień) pokrywy lodowej w 2007 i 2012 roku przyciągały wyjątkowo dużą uwagę mediów, światowej opinii publicznej, a w końcu też i decydentów. ${ }^{26}$ Jeżeli obecne tempo ocieplenia utrzyma się, istnieje spore prawdopodobieństwo, że w ciągu najbliższych 30 lat pokrywa lodowa na Oceanie Arktycznym w czasie lata zaniknie. Należy jednak pamiętać, że pokrywa lodowa w zimie będzie nadal obecna, co ma duże znaczenie dla perspektyw arktycznego transportu morskiego czy poziomu ryzyka związanego $\mathrm{z}$ wydobywaniem ropy, gazu lub innych surowców mineralnych $z$ dna morskiego. $Z$ drugiej strony, dalsze ocieplanie się wód oceanicznych na północy może mieć wpływ na migracje ławic ryb w obrębie szelfów kontynentalnych.

Warto podkreślić, iż dla mieszkańców Arktyki często istotniejsze niż zmniejszanie się letniej pokrywy lodowej na Oceanie Arktycznym są zmiany w pokrywie

${ }^{23}$ UNFCCC, Dane Ramowej Konwencji ONZ do sprawy Zmian Klimatu, dostępne na: http://unfccc.int/ghg_data/ghg_data_unfccc/items/4146.php (dsotęp: 18.01.2015).

${ }^{24}$ IPCC, Climate Change 2014: Impacts, Adaptation, and Vulnerability. Part B: Regional Aspects. Contribution of Working Group II to the Fifth Assessment Report of the Intergovernmental Panel on Climate Change, Cambridge University Press, Cambridge 2014), dostępne na: http:// ipcc-wg2.gov/AR5/images/uploads/WGIIAR5-PartB_FINAL.pdf (dostęp 10.01.2015).

${ }^{25}$ CAFF, Arctic biodiversity assessment: Report for policy makers 2013.

${ }^{26}$ Strategic Assessment of Development of the Arctic: Assessment conducted for the European Union, European Commission's Environment Directorate General, 2014, dostępne na: http:// arcticinfo.eu/images/pdf/SADA_report.pdf (dostęp: 14.02.2015). 
śnieżnej na lądzie i pokrywy lodowej na rzekach i jeziorach, co wpływa znacząco na turystykę, transport czy tradycyjne sposoby życia takie jak hodowla reniferów lub rybołówstwo. Przeobrażenia te znajdują też odbicie w stanie siedlisk przyrodniczych i kondycji fauny i flory arktycznej Wreszcie, ocieplająca się Arktyka wpływa na klimat Europy. Topnienie arktycznych lodowców wraz z termalnym rozszerzaniem się wody w oceanach, mają istotne znaczenie dla przewidywanego podnoszenia się globalnego poziomu mórz, co może stanowić zagrożenie dla europejskich wybrzeży. ${ }^{27}$

Ponadto Arktyka, z powodu swej ekologicznej wrażliwości i podatności na wpływy zewnętrzne, jest w szczególny sposób narażona na zagrożenia środowiskowe, których źródła i przyczyny znajdują się właśnie poza jej granicami. Dotyczy to przede wszystkim zmian klimatycznych i zanieczyszczeń mających daleki zasięg geograficzny. ${ }^{28} 293031 \mathrm{Z}$ drugiej strony, środowisko naturalne jest narażone na lokalne źródła zanieczyszczeń i zagrożeń, które są przede wszystkim związane z projektami wydobywczymi i transportem. Dodatkowo, wpływ zmian klimatycznych i środowiskowych na gospodarkę, kulturę i tradycyjny sposób życia w regionach arktycznych nie może być analizowany w oderwaniu od ogólnych przemian społecznych i gospodarczych.

Przedstawiona powyżej charakterystyka pewnego wycinka transformacji dokonującej się w Arktyce wydaje się dość dobrze korespondować z kategorią niepewności, jaka została wcześniej zaprezentowana. Ułomność modeli prognostycznych, brak odpowiednio szerokiego zakresu zbieranych danych, wreszcie wciąż raczej uboga wiedza na temat mechanizmów zmian klimatu wspólnie sprawiają, iż trudno w tym przypadku - zwłaszcza na poziomie politycznym, czy choćby ogólnospołecznym - podejmować jakiekolwiek spekulacje dotyczące przyszłości. Następstwa zmian klimatu to poniekąd klasyczny obszar niepewności, a zarazem dobry przykład tego, co za U. Beckiem i A. Giddensem można określić „bezgranicznym ryzkiem” będącym niezamierzonym efektem industrializacji. Czymś, co nie znając granic w przestrzeni i czasie ujawnia ograniczą użyteczność dotychczasowych form zabezpieczania się społeczeństw przed zagrożeniami i prowadzi do nowego etapu rozwoju społecznego, czyli światowego społeczeństwa ryzyka. ${ }^{32}$ Skoro zakres tej zmiany - oddziaływania

${ }^{27}$ EEA, Arctic environment: European perspectives: Why should Europe care?, Environmental issue report 38, European Environment Agency 2004, dostępne na: http://www.eea.europa. eu/publications/environmental_issue_report_2004_38/at_download/file (dostęp: 20.02.2015).

${ }_{28}$ ACIA, Arctic Climate Impact Assessment, Cambridge University Press, Cambridge 2004, dostępne na: http://www.amap.no/documents/download/1057 (dostęp: 22.01.2015).

${ }^{29}$ AMAP, Arctic pollution issues: A state of the Arctic environment report (Oslo: AMAP, 1997)

${ }^{30}$ AMAP, AMAP Assessment 2011: Mercury in the Arctic (Oslo, Norway: Arctic Monitoring and Assessment Programme, 2011)

${ }^{31}$ SWIPA, Changes in Arctic snow, water, ice and permafrost, with the assistance of Lynn Dicks, Rosamunde Almond, and Anna McIvor (2011)

${ }^{32}$ S. Hameiri, op. cit., s. 383-384. 
„bezgranicznego ryzyka” - jest aż tak wielki to nie sposób zanegować także jego wpływu na funkcjonowanie środowiska międzynarodowego.

\section{ZARZĄDZANIE RYZYKIEM JAKO ISTOTA WSPÓŁPRACY MIĘDZYNARODOWEJ W ARKTYCE}

Międzynarodowe znaczenie Arktyki było przez stulecia i jest nadal funkcją właściwości klimatycznych, geograficznych oraz przyrodniczych środowiska naturalnego tego regionu oraz możliwości jej eksplorowania, kolonizowania i eksploatowania. ${ }^{33}$ Wiele dokumentów źródłowych wskazuje, iż możliwości te zawsze były (tak jak i są obecnie oraz zapewne będą w przyszłości) pochodną zdolności przybyszów z Południa do wytrwałego zmagania się z naturalnymi warunkami Dalekiej Północy ${ }^{34}$, szczególnie zaś adaptowania się do surowego klimatu oraz zjawiska dnia i nocy polarnej, pokonywania wielu wyzwań pogodowych, a wreszcie umiejętności przetrwania w arktycznym środowisku naturalnym. ${ }^{35}$

Abstrahując w tym miejscu od zamieszkiwania obszarów subarktycznych przez rdzenne ludy Arktyki, można przyjąć, iż nie tylko aktywność, ale już sama obecność człowieka na Dalekiej Północy wiązała się dla niego z wieloma zagrożeniami. Arktyka jest zatem regionem o szczególnie podwyższonym stopniu ryzyka dla człowieka. Z drugiej zaś strony, obecność i aktywność na Dalekiej Północy człowieka z Południa, a nawet ,tylko" jego działalność przemysłowa prowadzona w ostatnich dziesięcioleciach na niższych szerokościach geograficznych (której skutki są relatywnie łatwo przenoszone na Północ) stanowi zagrożenie dla wyjątkowo kruchej równowagi środowiska naturalnego Arktyki. ${ }^{36}$

Coraz większa świadomość specyfiki tych relacji oraz dość często przeciwstawne dążenia różnych grup ludzi oraz instytucji sprawiły, że mniej więcej od lat

${ }^{33}$ M. Łuszczuk, Wprowadzenie [w:] Arktyka na poczatku ..., op. cit., s. 10.

${ }^{34}$ B. Imbert, Wielkie wyprawy polarne, Wydawnictwo Dolnośląskie, Wrocław 1996.

${ }^{35}$ Południowe kresy Arktyki przez tysiące lat były zamieszkiwane przez plemiona, które przybyły na te obszary podążając za cofającymi się lodowcami lub dotarły na Północ w późniejszych epokach. Proces osiedlania się przebiegał bowiem odmiennie w różnych częściach Arktyki, np. podaje się, iż Saamowie mieszkają na północy Skandynawii już od 5000 lat, zaś Inuici zasiedlający obecnie kanadyjską Arktyką oraz Grenlandię przybyli na te tereny dopiero między X-XIII wiekiem). Niezależenie od momentu zamieszkania Arktyki jej rdzenni mieszkańcy żyjąc przez stulecia w niemal całkowitej izolacji i w zgodzie ze swoimi obyczajami i wierzeniami, potrafili doskonale zaadoptować się do warunków Dalekiej Północy. Dopiero wraz z coraz większą obecnością Europejczyków „odkrywających”, eksploatujących i zawłaszczających obszary arktyczne, rdzenne plemiona zaczęły w ograniczonym zakresie stopniowo rozwijać kontakty ze światem zewnętrznym. Relacje te wkrótce przybrały postać różnych praktyk dyskryminacyjnych ze strony Europejczyków, w tym też działań kulturowych, religijnych, politycznych, ekonomiczno-społecznych podejmowanych w ramach ,wewnętrznej kolonizacji” prowadzonej w Kanadzie, Rosji i w państwach nordyckich.

${ }^{36}$ New Awareness of and Opportunities for UNEP to Address Climate Change in Arctic, UNEP 2013, http://www.unep.org/gc/gc27/Docs/se/What\%20Future\%20for\%20the\%20Arctic.pdf (dostęp: 18.02.2014). 
70. XX wieku troska o ograniczenie następstw negatywnych zjawisk i procesów coraz częściej spotykanych w Arktyce stała się fundamentem panregionalnej współpracy podejmowanej na różnych poziomach. Jej początkiem byłą oficjalna międzynarodowa współpraca naukowa, do której doszło dzięki ociepleniu relacji między Wschodem a Zachodem w okresie zimnej wojny. Jej powodzenie umożliwiło następnie rozwój kontaktów lokalnych między organizacjami reprezentującymi arktyczne ludy rdzenne. Ważnym momentem rozwoju współpracy arktycznej było przemówienie Michaiła Gorbaczowa wygłoszone w Murmańsku w 1987 roku, w którym ostatni przywódca ZSRR ogłosił Arktykę strefą pokojowej współpracy. ${ }^{37}$ To nowe, otwarte podejście ze strony ZSRR rzeczywiście zaowocowało w kolejnych latach serią inicjatyw, głównie fińskich i kanadyjskich w zakresie kooperacji państw arktycznych, przede wszystkim w zakresie dość szeroko rozumianego bezpieczeństwa ekologicznego.

Po zakończeniu zimnej wojny rozpoczął się zatem proces instytucjonalizacji „miękkiej” współpracy wokół bieguna północnego (z której wyłączono kwestie dotyczące bezpieczeństwa militarnego), głównie w ramach powołanej w 1996 roku Rady Arktycznej. Jej aktywność, jako forum kooperacji międzynarodowej państw arktycznych przede wszystkim w zakresie problematyki ekologicznej i współpracy naukowej, przez długi okres czas nie cieszyła się specjalną uwagą opinii międzynarodowej. Sytuacja ta stopniowo zaczęła ulegać zmianie na początku XXI wieku, kiedy to głównie dzięki rezultatom prac grup roboczych Rady Arktycznej zajmujących się między innymi monitorowaniem zmian środowiska naturalnego obszarów arktycznych zaczęto coraz wyraźniej dostrzegać bardzo rozległy zakres następstw procesów klimatycznych.

Generalnie można uznać, iż system instytucjonalny współpracy międzynarodowej w Arktyce stanowi odzwierciedlenie złożonej i zróżnicowanej natury tego regionu oraz specyfiki zachodzących w nim relacji międzynarodowych. Zarządzanie (governance) w Arktyce nie jest ograniczone do jednej instytucji czy organizacji, lecz jest realizowane na różnych poziomach współpracy. ${ }^{38}$ Jedną z konsekwencji tej różnorodności jest udział w systemie wielu aktorów, zarówno

${ }^{37} \mathrm{~K}$. Åtland, Mikhail Gorbachev, the Murmansk Initiative, and the Desecuritization of Interstate Relations in the Arctic, „Cooperation and Conflict” 2008, vol. 43, s. 289-311.

${ }^{38}$ Należy w tym miejscu podkreślić, iż termin zarządzanie (governance) nie jest używane oficjalnie przez państwa arktyczne z powodu obiekcji Rosji, Kanady i Stanów Zjednoczonych. Zdecydowanie częściej stosuje się więc pojęcia "współpracy międzynarodowej” (international cooperation/collaboration) lub "sprawowania pieczy/dozorowania" (stewardship). Wynika to z przekonania, że termin governance implikuje jakąś formę rządzenia czy wręcz istnienia grupy lub instytucji mogącej podejmować wiążące dla stron trzecich decyzje, co w Arktyce nie ma miejsca. Należy jednak zgodzić się z opinią P. Graczyka, iż sytuacja w Arktyce i działania państw arktycznych wypełniają większość definicji terminu governance. Zob.: P. Graczyk, A. Stępień, M. Śmieszek, M. Łuszczuk, Zarządzanie regionem i międzynarodowa wspótpraca polityczna, [w:] Cele i narzędzie ..., op. cit. 
państwowych jak i niepaństwowych, choć z oczywistych powodów dominują w niej państwa arktyczne. ${ }^{39}$

Deklaracja ustanawiająca Radę Arktyczną (Declaration on the Establishment of the Arctic Council) została podpisana dnia 19.09.1996 roku w Ottawie i na jej podstawie Rada jest jedynym międzyrządowym forum wysokiego szczebla (high level forum) ośmiu państw arktycznych. Warto podkreślić, iż nie jest przy tym organizacją międzynarodową $\mathrm{w}$ rozumieniu prawa międzynarodowego, jak też nie jest za taką uważana przez uczestniczące w niej strony. Sytuacja ta wynika w głównej mierze z niechęci Stanów Zjednoczonych do wchodzenia w wiążące zobowiązania międzynarodowe mogące ograniczyć swobodę ich działania, oparte na obowiązkowych nakładach finansowych lub też dotyczących kwestii niewygodnych lub też istotnych $\mathrm{z}$ punktu bezpieczeństwa narodowego. $\mathrm{Z}$ tych też powodów Rada Arktyczna, powołana do istnienia na mocy deklaracji, a nie traktatu, uważana jest za instytucję ,miękkiego" prawa (soft-law) międzynarodowego, opartą na dobrowolnym uczestnictwie i angażowaniu środków.

Głównym celem utworzenia Rady było zapewnienie środków dla promocji współpracy, koordynacji i interakcji między państwami arktycznymi, z udziałem arktycznych rdzennych społeczności i innych mieszkańców. Mandat Rady Arktycznej obejmuje więc wspólne problemy arktyczne, w szczególności kwestie zrównoważonego rozwoju i ochrony środowiska naturalnego w Arktyce. W pewnym sensie mandat ten można uznać za otwarty, wszakże z jednym, za to bezpośrednio wyrażonym, wyjątkiem odnoszącym się do zagadnień związanych $\mathrm{z}$ bezpieczeństwem militarnym.

Podstawę funkcjonowania Rady Arktycznej tworzą trzy fundamentalne dokumenty: Deklaracja o ustanowieniu Rady Arktycznej (Ottawa Declaration 1996), Reguły Procedowania Rady Arktycznej (Arctic Council Rules of Procedure), przyjęte w 1998 r. w Iqaluit i uaktualnione na spotkaniu ministerialnym w Kirunie w maju 2013 r., oraz Zakres Działania (Uprawnień) Programu na rzecz Zrównoważonego Rozwoju (Terms of Reference for Sustainable Development Program). Jak uważa P. Graczyk, struktura Rady Arktycznej oparta jest na trzech zasadniczych poziomach: politycznym (spotkania ministrów i wiceministrów), wykonawczym (Senior Arctic Officials - SAOs) i roboczym (grupy robocze i grupy zadaniowe - task forces) ${ }^{40}$

${ }^{39}$ Również między nimi istnieją jednak pewne różnice w roli, poziomie zaangażowania i możliwości współdecydowania o sprawach regionu. Największe znaczenie ma pod tym względem pięć państw nadbrzeżnych Oceanu Arktycznego - Królestwo Danii (z Grenlandią i Wyspami Owczymi), Kanada, Norwegia, Federacja Rosyjska i Stany Zjednoczone. Niekiedy do grona tych państw zaliczana jest również Islandia (jako szósty członek), jednak odbywa się to raczej na poziomie akademickim, niż politycznym. Najczęściej łączona jest ona z Finlandią i Szwecją, jako pozostałymi państwami członkowskimi Rady Arktycznej. Razem owe osiem państw tworzy grupę państw arktycznych. Zob. M. Łuszczuk, Ewolucja ról międzynarodowych w regionie Arktyki, Wydawnictwo UMCS, Lublin 2015.

${ }^{40}$ P. Graczyk, A. Stępień, M. Śmieszek, M. Łuszczuk, Zarządzanie regionem i międzynarodowa wspótpraca polityczna, [w:] Cele i narzędzie ..., op. cit., s. 54. 
Najważniejsza rangę mają organizowane co dwa lata (na zakończenie okresu przewodnictwa) spotkania ministerialne, na które zazwyczaj są delegowani ministrowie spraw zagranicznych lub ministrowie ds. ochrony środowiska. ${ }^{41}$ To w ich gestii znajdują się decyzje odnośnie zaakceptowania oraz wskazania sposobów wdrożenia przygotowanych wcześniej projektów, jak również aplikacji o status stałego uczestnika lub obserwatora. Do kompetencji ministrów należy także nadzór nad realizowanymi już projektami, jak również ocena prac tzw. Senior Arctic Officials. ${ }^{42}$ Bardzo ważną rolę odgrywają w tym systemie właśnie Senior Arctic Officials, którzy spotykają się z reguły dwa razy w roku. W zakresie ich odpowiedzialności jest ogólne nadzorowanie postępów prac w Radzie, przygotowanie spotkań ministerialnych, pełnią oni również funkcję łączników między ministrami a grupami roboczymi (przekładając wyniki badań na cele polityczne). ${ }^{43}$

Podstawowym komponentem roboczym Rady Arktycznej (RA) jest sześć grup roboczych (odpowiadających za większość projektów Rady) oraz grupy zadaniowe. Do sześciu stałych grup roboczych RA należą: Arctic Monitoring and Assessment Programme (AMAP), Protection of the Arctic Marine Environment (PAME), Conservation of Arctic Flora and Fauna (CAFF), Emergency Prevention Preparedness and Response (EPPR), Sustainable Development Working Group (SDWG) i Arctic Contaminants Action Program (ACAP). Jak wyjaśnia P. Graczyk, zadaniem AMAP jest „,dostarczanie Radzie rzetelnych i wyczerpujących informacji na temat stanu i zagrożeń dla środowiska naturalnego Arktyki oraz doradztwo naukowe na temat działań, jakie należy podjąć w celu wspierania rządów państw arktycznych w ich dążeniach do integracji działań naprawczych i zapobiegawczych dotyczących zanieczyszczeń i skutków zmiany klimatu". ${ }^{4}$ Natomiast aktywność PAME skoncentrowana jest na zagadnieniach z zakresu ochrony i zrównoważonego korzystania ze środowiska morskiego Arktyki, gdyż „ma ona szczególny mandat do monitorowania możliwości stosowania globalnych i regionalnych środków politycznych, prawnych i innych, oraz, gdy jest to konieczne, przedstawiania rekomendacji". ${ }^{45} \mathrm{Z}$ kolei działalność grupy roboczej CAFF jest skierowana na wymianę informacji w zakresie metod zarządzania oraz systemów regulacyjnych dotyczących bioróżnorodności regionu, jak też wspieranie procesu podejmowania decyzji w oparciu o wiedzę naukową. ${ }^{46} \mathrm{Jej}$ zadaniem jest także wspieranie mechanizmu ,rozwijania wspólnych działań istotnych dla

${ }^{41}$ Do tej pory odbyło się osiem spotkań ministerialnych: Iqaluit (kończące kanadyjskie przewodnictwo, 1996-1998), Barrow (USA, 1998-2000), Inari (Finlandia, 2000-2002), Rejkjavik (Islandia, 2002-2004), Salechard (Rosja, 2004-2006), Tromsø (Norwegia, 2006-2009), Nuuk (Dania/Grenlandia, 2009-2011) Kiruna (Szwecja, 2011-2013) oraz Iqaluit (Kanada, 2013-2015).

${ }^{42}$ Ibidem, s. 54.

${ }^{43}$ Ibidem, s. 55.

${ }^{44}$ Ibidem.

${ }^{45}$ Ibidem, s. 56.

${ }^{46}$ Ibidem. 
funkcjonowania ekosystemu Arktyki". ${ }^{47}$ Grupa robocza EPPR w zakresie swej działalności ma zagadnienia dotyczące przeciwdziałania, gotowości i reagowania w sytuacjach kryzysowych, które mogą wystąpić na obszarze Arktyki. Przede wszystkim ,stanowi ona forum wymiany informacji na temat najlepszych praktyk i prowadzenia projektów obejmujących rozwój doradztwa i metodologii oceny ryzyka, ćwiczenia reagowania kryzysowego i szkoleń. Celem EPPR jest przyczynienie się do ochrony środowiska Arktyki od niebezpieczeństwa przypadkowego uwolnienia zanieczyszczeń lub radionuklidów. Mandat grupy obejmuje również kwestie związane ze skutkami klęsk żywiołowych". ${ }^{48}$ Jak wyjaśnia P. Graczyk, „grupa robocza SDWG proponuje i realizuje projekty przyczyniające się do postępu w zrównoważonym rozwoju Arktyki. Projekty te dotyczą ochrony środowiska naturalnego i wzmocnienia stanu lokalnych gospodarek, kultury oraz zdrowia ludności rdzennej i mieszkańców Arktyki. Celem współpracy w ramach grupy jest więc poprawa warunków środowiskowych, gospodarczych i społecznych mieszkańców Arktyki jako całości". ${ }^{49}$ Natomiast grupa ACAP w ramach swych prac zajmuje się projektami służącymi ograniczeniu emisji zanieczyszczeń do środowiska Arktyki. „Odbywa się to poprzez proponowanie rządom państw arktycznych naprawczych i zapobiegawczych działań wewnętrznych dotyczących emisji zanieczyszczeń. Grupa stanowi mechanizm wzmacniający wewnętrzne działania w celu redukcji emisji i innych uwolnień zanieczyszczeń". ${ }^{0}$

Zdaniem P. Graczyka „Rada Arktyczna stanowi w sumie forum opracowujące zalecenia techniczne, wytyczne i oceny naukowe dotyczące Arktyki. Dotychczas nie jest (jeszcze) organem regulacyjnym, choć coraz częściej analizom naukowym towarzyszą rekomendacje polityczne sugerujące rozwój prawnie wiążących umów pod auspicjami Rady Arktycznej”. ${ }^{51}$ Od 2011 roku Rada stanowi też platformę przygotowywania wiążących umów o charakterze pan-arktycznych. Należą do nich: Umowa o współpracy w dziedzinie lotniczego i morskiego poszukiwania i ratownictwa w Arktyce (Porozumienie SAR) ${ }^{52}$ i Umowa o współpracy w kwestii gotowości i reagowania na zanieczyszczenia obszarów morskich olejem w Arktyce (Porozumienie MOPPR).$^{53}$ Według tego Autora, „obie umowy mają znaczenie, szczególnie w wymiarze politycznym i symbolicznym, a do pewnego stopnia
${ }^{47}$ Ibidem.
${ }^{48}$ Ibidem.
${ }^{49}$ Ibidem.
${ }^{50}$ Ibidem.
${ }^{51}$ Ibidem, s. 57.
${ }^{52}$ Agreement on Cooperation on Aeronautical and Maritime Search and Rescue in the Arctic, 2011, dostęp: https://oaarchive.arctic-council.org/bitstream/handle/11374/531/Arctic_SAR_ Agreement_EN_FINAL_for_signature_21-Apr-2011\%20\%281\%29.pdf?sequence $=1 \&$ isAllowed $=\mathrm{y}$.

${ }^{53}$ Agreement on Cooperation on Marine Oil Pollution Preparedness and Response in the Arctic, 2013, dostęp: https://oaarchive.arctic-council.org/bitstream/handle/11374/529/MM08_agree ment_on_oil_pollution_preparedness_and_response_\%20in_the_arctic_formatted $\% 20 \% 282 \% 29$. pdf? sequence $=1 \&$ isAllowed $=y$ 
również prawnym". ${ }^{54}$ Warto też podkreślić, iż są one pierwszymi prawnie wiążącymi instrumentami odnoszącymi się do kwestii związanych z bezpieczeństwem prowadzenia działalności gospodarczej w regionie Arktyki. ${ }^{55}$

Jak ocenia P. Graczyk, mimo, że ,dokumenty te nie dokonały znacznej zmiany jakościowej w zachowaniu państw, to umieszczenie Rady Arktycznej w centrum obu procesów negocjacyjnych spowodowało istotne wzmocnienie jej profilu w arktycznym systemie zarządzania. (...) Co więcej, państwa arktyczne wykazały się innowacyjnością i kreatywnego podejścia do ograniczeń narzuconych przez samych siebie na Radę. Ponieważ zmiany w Arktyce, w tym w sytuacji gospodarczej, cechują się znaczną dynamiką, państwa arktyczne, zdecydowały się działać mniej zdecydowanie, ale szybciej". ${ }^{56}$

Jak wynika z przedstawionej ogólnej charakterystyki zakresu i sposobu działania Rady Arktycznej dokładnie zrekonstruowanej przez P. Graczyka ${ }^{57}$, pełni ona wiele funkcji, których realizacja na poziomie państwowym lub w ramach dwustronnych stosunków byłaby raczej niemożliwa. Wyzwania o charakterze transnarodowym mogą być podejmowane z szansą na sukces głównie na poziomie regionalnym. Świadczy o tym, między innymi to, że wiedza generowana przez Radę Arktyczną okazała się mieć daleko idące konsekwencje dla polityki regionalnej.

Rada z powodzeniem podejmowała się zarządzania politycznymi konsekwencjami odkryć naukowych dotyczących przeobrażeń zachodzących w regionie za sprawą zmian klimatu, modernizacji czy globalizacji, dzięki czemu zaczęła pełnić rolę forum kształtującego relacje międzynarodowe i wyznaczającego kierunki ich rozwoju. Co jest szczególnie istotne, wiele z obszarów aktywności Rady Arktycznej mieści się w zakresie zarządzania ryzykiem zawiązanym $\mathrm{z}$,otwieraniem się" Arktyki, w tym też z ewentualnymi nieporozumieniami natury politycznej.

Ten wymiar funkcjonowania Rady Arktycznej wpisuje się w to co U. Beck i A. Giddens określili mianem „refleksyjnej modernizacji” polegającej na rozwijaniu pogłębionych pod względem analitycznym podejść i form działania obejmujących m.in. nieustanne wysiłki na rzecz identyfikacji źródeł ryzyka, określenia stopnia ich oddziaływania oraz podejmowania odpowiednich działań we właściwym momencie..$^{58}$ Jednocześnie trudno w tym miejscu - znając specyfikę Rady Arktycznej oraz rolę jaką odgrywają w niej państwa - nie wspomnieć o propozycji Merlingena dotyczącej wykorzystania koncepcji „rządomyślności” M. Foucault do analizy funkcjonowania organizacji międzynarodowych. ${ }^{59} \mathrm{Zgod}-$

${ }^{54}$ P. Graczyk, A. Stępień, M. Śmieszek, M. Łuszczuk, Zarządzanie regionem i międzynarodowa wspótpraca polityczna, [w:] Cele i narzędzie ..., op. cit., s. 58.

${ }_{55}$ Op. cit., s. 58.

${ }^{56}$ Op. cit., s. 58

${ }^{57}$ Op. cit., s. 51-58.

${ }^{58}$ S. Hameiri, op. cit., s. 384.

${ }^{59}$ M. J. Williams, op. cit.; M. Merlingen, Governmentality. Towads a Foucauldian Framework for the Study of IGOs, "Cooperation and Conflict" 2008, t. 38, nr 4, s. 361-384. 
nie $\mathrm{z}$ tą koncepcją prowadzenie analiz naukowych dotyczących ryzyka, a następnie przekładanie ich na działania polityczne (czyli w sumie zarządzanie ryzykiem) stanowi bardzo ważny element kreowania, a zarazem stosowania władzy (power) w obliczu zagrożeń. Zdolność do opisywania ryzyka w tym ujęciu można uznać za neoliberalne narzędzie do sterownia zachowaniami członków społeczności międzynarodowej, a więc docelowo wpływania na środowisko międzynarodowe. Jest to szczególnie widoczne w przypadku, gdy zarządzanie ryzykiem dotyczy zagrożeń transnarodowych. W tym miejscu wracamy do opisu funkcjonowania późnowestfalskiego środowiska międzynarodowego, którego elementem charakterystycznym jest deterytorializacja zjawisk i procesów. Kwestia czy dotyczy to również kategorii władzy we wciąż anarchicznym systemie międzynarodowym pozostaje nierozstrzygnięta.

Dodatkowo warto też podkreślić element tożsamości i świadomości poszczególnych uczestników stosunków międzynarodowych w regionie Arktyki. Jest on współkształtowany zarówno przez ich doświadczenia dotychczasowego eksploatowania Dalekiej Północy, jak i ogólną politykę władz wyrażającą troskę (lub jej brak) o przyszłe bezpieczeństwo w obliczu gromadzących się zagrożeń. Liczne dylematy dotyczące następstw zmian klimatu w Arktyce oraz zarysowujących się szans (w wymiarze gospodarczym) rozwój ludzkiej aktywności w regionie są rozmaicie postrzegane i rozwiązywane przez poszczególne państwa arktyczne. Może to świadczyć, iż w gruncie rzeczy zarządzanie ryzykiem opiera się na decyzjach natury politycznej, czego przykładami mogą być deklaracje i działania takich państw jak Kanada czy Rosja, które w wymiarze praktycznym wydają się preferować unikanie tematu zagrożeń ekologicznych, zaś niepewność rozpatrują głównie w kategoriach problemu nieokreślonej przyszłości. W tym kontekście współpraca międzynarodowa, a szczególnie działalność Rady Arktycznej stanowią ważne ramy wyznaczające granice zakresu odpowiedzialności państw za ich postępowanie w obliczu niepewności i ryzyka w regionie Arktyki.

\section{PODSUMOWANIE}

Traktując region Arktyki jako podsystem współczesnego systemu międzynarodowego należy zwrócić uwagę, iż w ostatnich latach jest on słusznie przedstawiany jako obszar szczególnie wielu bezprecedensowych zjawisk i procesów generowanych przez zmianę klimatu, modernizację oraz globalizację. Te trzy wzajemnie powiązane i wielowymiarowe zjawiska stanowią obecnie główne źródła dokonującej się fundamentalnej transformacji całego regionu Dalekiej Północy. Stanowią one również źródło niepewności i uzasadnienie dla analizowania generowanych zagrożeń i związanego z nimi ryzyka. W obliczu specyfiki (odmienności) podejść poszczególnych państw regionu do tej problematyki istotną rolę „edukacyjną" oraz organizacyjną w zakresie zarządzania ryzykiem w Arktyce coraz wyraźniej pełni Rada Arktyczna. Należy przypuszczać, iż w naj- 
bliższym czasie coraz bardziej będzie ona dalej ewoluować od funkcji ,jedynie” forum dyskusji w stronę instytucji nastawionej na ograniczanie ryzyka rozwoju niekorzystnych zmian w regionie Pomimo, iż jak dotąd dorobek teoretyczny nauki o stosunkach międzynarodowych dotyczący badania niepewności i ryzyka jest stosunkowo mały, to wydaje się, że jego rozwój jest nieodzowny. Bez lepszego poznania ograniczeń w zakresie wiedzy na temat środowiska międzynarodowego i jego funkcjonowania, a szczególnie specyfiki ryzyka zagrożeń, jego analiza wciąż będzie ułomna.

\title{
UNCERTAINTY AND RISKS AS CATEGORIES OF ANALYSIS OF THE INTERNATIONAL ENVIRONMENT IN THE ARCTIC REGION
}

\begin{abstract}
The article considers the importance of examining uncertainty and risk as important factors influencing the functioning of the contemporary international system. Building on an analysis of international developments taking place in the Arctic region at the beginning of the $21^{\text {st }}$ century, the article examines the impact of uncertainty on Arctic affairs stemming from the climate change and how international cooperation in the region is becoming more and more oriented towards risk management.
\end{abstract}

Keywords: risk, uncertainty, analysis of international relations, Arctic 